mentioned. The small-scale maps, namely, those on the 1 -in. and smaller scales, present no problem. The large-scale plans, which are numbered by tens of thousands, have been gradually getting very much out of date. This is mainly due to two causes : the action of the Geddes Committee of 1922 in recommending further reductions in an already reduced department, and the great alteration in the countryside caused by the expansion of the built-up area and the spread of 'ribbon development'. There is also the further difficulty that, simultaneously with the enforced slowing up of revision, there has been an increased demand for the large-scale plans for town planning and for land registration. It is clearly high time that the whole matter was examined. Many interests are involved, as is indicated by the fact that no fewer than six public departments are represented on the Committee. The question is somewhat urgent, and it is to be hoped that the Committee may be able to report speedily, for every month the arrears become more serious. There is one curious item in the terms of reference; the Committee is to "review the scales and styles of Ordnance Survey maps placed on sale". It is not to be desired that we should enter again upon the 'battle of the scales' which was happily decided more than two generations ago. Nothing has happened since then to throw doubt upon the wisdom of the choice of the 25 -in. scale as that of our principal large-scale plans. That old 'battle of the scales' lasted from 1840 until 1863, and since the latter date the country has enjoyed, in this matter, the great advantage of an uninterrupted, continuous policy.

\section{Civil Aircraft in the Royal Air Force}

THE Air Ministry has acquired a De Havilland Dragon Rapide and an Avro Ava, two well-known commercial types of aircraft, for R.A.F. use. Such purchases indieate two possible lines of attack on the problem of rapid expansion recently announced. The degree of military usefulness of such machines, and the amount of modification necessary, can be studied in actual experiment by the R.A.F. personnel concerned. Also the more immediate problem of obtaining a sufficient supply of machines for training and flying practice, for the increased establishment under the new R.A.F. expansion scheme, will be helped, if civil machines are found suitable, and can be built immediately in factories already in produc. tion of them. It is understood that the first two of the five new training schools are to be opened this month, each school having the equivalent of three squadrons. Thus the problem of equipment is not only to supply these, but also a progressively increasing number of machines for the use of these pupils as they pass out into the service. It has to be discovered whether it is best to allow constructing firms to accelerate the production of their own aircraft, modified to R.A.F. requirements, or to change them over to contracts to build other machines specifically designed for R.A.F. work. Large contracts have also been placed for the construction of aeroplane hangars in various places.

\section{German Commercial Airship Plans}

The new Zeppelin, Airship L.Z. 129, is now reported to be complete in skeleton, and work on covering has commenced. It is hoped to launch it at the end of July. When completed it will be the largest airship in the world. It is $813 \mathrm{ft}$. in length, $135 \mathrm{ft}$. maximum diameter, and has gas capacity of 6,720,000 cubic feet. Dr. Eckener says that he intends to build three further ships for routes across the North Atlantic, South Atlantic, and to India and Batavia, that will operate under American, German and Dutch control respectively. The German operating base will be changed from Friedrichshafen to Frankfort, which is not only more convenient for commercial traffic but is also at a lower altitude. The loss of available lift due to starting from the higher altitude of Friedrichshafen is estimated to be about three tons for the L.Z. 129. Arrangements have also been completed for the construction of a mooring mast and gas plant at Seville, in conjunction with the Atlantic routes. A new operating company, in which the German Government is said to be interested, is being formed with a capital of about $£ 835,000$.

\section{The Admiralty Magnetic Survey Ship}

AT the sixteenth annual meeting of the American Geophysical Union, held at Washington on April 26, the following resolution was adopted: "WHEREAS, The magnetic survey of the oceanic areas, carried on for 25 years by the Carnegie Institution of Wash. ington, was brought to a sudden end by the destruction of the Carnegie at Apia, Western Samoa, November 29, 1929, in the course of a cruise designed to determine the secular change of the Earth's magnetism in all oceans, and WhErEAs, It is of very great importance, not only for the practical needs of the navigator but also for the effective study of the Earth's magnetism, that these observations be resumed at an early day, and Whereas, It has been announced that the British Admiralty has decided to build a non-magnetic vessel, designed primarily for securing magnetic data at sea, therefore be it Resolved, That the American Geophysical Union is highly gratified at this action of the British Government, assuring, as it does, the continuance of the ocean magnetic work, and expresses the hope that the construction and equipment of the vessel may be pushed to a speedy conclusion, and be it further Resolved, That a copy of this resolution be sent to the British Admiralty, to the Astronomer Royal, and to the Chairman of the British National Committee for Geodesy and Geophysies." In transmitting this resolution, Dr. Isaiah Bowman, chair. man of the National Research Council, writes, "All geophysicists must extend grateful thanks to the British Admiralty in making possible the further accumulation of data so essential to the needs of navigators and of scientific enquiry".

\section{Noise Abatement Exhibition at the Science Museum}

ON May 31, the Prime Minister opened the Noise Abatement Exhibition which has been organised by 
the Anti-Noise League and is being held at the Science Museum, South Kensington, during this month. The opening ceremony was held in the lecture theatre, and was attended by some two hundred guests. The chair was taken by Lord Horder, chairman of the Council of the Anti-Noise League. Mr. MacDonald in his speech opening the exhibition said that formerly a person who confessed that he was troubled by noise was put down as an irreparable crank; but now it is rightly regarded that noise is something that ought not to be tolerated by any decent man or woman. He suggested that their campaign against nerve jarring should be regarded as a great movement in æstheticism. It is the duty of all to co-ordinate in the protection of life from jars of the eye and the nerves-jars of the complete human personality. Sir Henry Richards, chairman of the Executive Committee of the Anti-Noise League, in moving a vote of thanks to the Prime Minister, said that the League is an educational body and the exhibition is intended to show to the public the means of escape from noise. The Prime Minister made a short tour of the exhibition and inspected among other things a silenced pneumatic road-drill, a silenced motor-cycle engine, a ripple tank illustrating the behaviour of sound-waves from a speaker in the House of Commons and several models demonstrating the scientific principles of the reduction of noise from machinery and in buildings.

\section{The Health of Sunderland and County Durham}

Dr. G. F. WALken, of Sunderland, in a letter to The Times last December, made an appeal that the deterioration of health of a section of the population in Sunderland and adjacent districts in County Durham, where unemployment has been severe and prolonged, was serious, and deserved more national consideration. In consequence of statements made in Dr. Walker's letter, the Ministry of Health instituted an inquiry by Dr. Pearse, Ministry of Health, Dr. Glover, Board of Education, and Mr. Grant, Ministry of Health, whose report has now been issued ("Report of an Inquiry into the Effects of Existing Economic Circumstances on the Health of the Community in the County Borough of Sunderland and certain districts of County Durham. London : H.M. Stationery Office, 1935. 9d. net). The matter of this report is too lengthy to quote in detail, but is summarised in the concluding paragraph. While admitting that there may be some slight deterioration of health and small increase in the incidence of certain diseases, the investigators state that "We are unable to accept Dr. Walker's statement that there has been in this area a 'substantial and progressive deterioration in public health" ".

\section{Technological Advances of the Past Twenty-five Years}

Sir Frank Smith, secretary of the Department of Scientific and Industrial Research, spoke on June 3 at a special Jubilee luncheon, held under the auspices of the Society of Engineers, on "Some Significant Technological Achievements of the King's Reign" Sir Frank dealt with four outstanding types of achievement of the period. The first was the advances in medicine which have prolonged our lives; the second was the more complete harnessing of the electron, an achievement which has given birth to industries unknown in 1910 ; the third was the fixation of nitrogen, an achievement which has overthrown the menace to our food supplies resulting from diminishing quantities of Chile nitrate; and finally, the production of new steel cutting tools, which has largely affected mechanisation, the price of manufactured goods and the leisure of man. Speaking of the industrial applications arising from the discovery of the electron, and the researches of Sir J. J. Thomson and Lord Rutherford and others on the structure of the atom and on matter in general, Sir Frank said : "When the King came to the throne there was not one listener in the world, for there was no broadcasting station. To-day in this country alone there are over 7 million people with licensed receivers. There are millions of thermionic valves in use, and on his Jubilee day the King spoke via millions of thermionic valves to hundreds of millions of his subjects. The radio engineer was in charge, and by the simple operation of switches, millions and millions of electrons played the parts arranged for them beforehand." The turnover in the radio broadcasting industry, which did not exist twenty-five years ago, was more than 20 millions sterling last year. The harnessing of the electron has been, in Sir Frank's opinion, one of the greatest achievements of the King's reign. It enables one person to speak to and be heard by the whole of the civilised world; it has increased entertainment and amusement through the 'talkies', and it has enabled our homes, our roads and our public buildings to be illuminated in a manner which many would have thought impossible twenty-five years ago.

\section{British Standards Institution}

THe annual meeting of the British Standards Institution was held on May 28, with Dr. E. F. Armstrong in the chair, who, in presenting the report, said the year's work showed marked progress in every section. He laid stress on the fact that more than 150,000 copies of the British Standard Specifcations have been sold and distributed during the year, an increase over last year of 23,000 , and that there are now 700 committees holding more than 1,000 meetings a year, the total membership exceeding 5,000 . The machinery of the B.S.I. is such that no section of industry need fear that its considered views will not receive the fullest consideration, or that a British Standard Specification would be issued in the face of soundly based objection. Moreover, it has been definitely stated that the Institution does not contemplate setting itself up as a testing authority. Mr. W. Reavell, a past-president of the Institution of Mechanical Engineers, has been elected chairman for the ensuing year. He was one of the first to recognise the necessity for the co-ordination of the work of mechanical standardisation, in which the Institution of Mechanical Engineers is taking a leading part. Perhaps one of the most important results of the year's work is the increasing success of the interImperial co-operation which is now so firmly 